\title{
Artemisia spp. essential oils against the disease-carrying blowfly Calliphora vomitoria
}

\author{
Stefano Bedini ${ }^{1}$, Guido Flamini ${ }^{2}$, Francesca Cosci ${ }^{1}$, Roberta Ascrizzi ${ }^{2}$, Maria Cristina Echeverria ${ }^{3}$, Lucia Guidi ${ }^{1}$, \\ Marco Landi ${ }^{1}$, Andrea Lucchi ${ }^{1}$ and Barbara Conti ${ }^{1 *}$
}

\begin{abstract}
Background: Synanthropic flies play a considerable role in the transmission of pathogenic and non-pathogenic microorganisms. In this work, the essential oil (EO) of two aromatic plants, Artemisia annua and Artemisia dracunculus, were evaluated for their abilities to control the blowfly Calliphora vomitoria. Artemisia annua and A. dracunculus EOs were extracted, analysed and tested in laboratory bioassays. Besides, the physiology of EOs toxicity and the EOs antibacterial and antifungal properties were evaluated.

Results: Both Artemisia EOs deterred C. vomitoria oviposition on fresh beef meat. At $0.05 \mu \mathrm{cm}^{-2}$ A. dracunculus EO completely inhibited C. vomitoria oviposition. Toxicity tests, by contact, showed $\mathrm{LD}_{50}$ of 0.49 and $0.79 \mu \mathrm{EO}$ per fly for $A$. dracunculus and A. annua, respectively. By fumigation, $L C_{50}$ values were 49.55 and $88.09 \mu^{\prime-1}$ air for $A$. dracunculus and $A$. annua, respectively. EOs AChE inhibition in C. vomitoria $\left(I C_{50}=202.6\right.$ and $472.4 \mathrm{mg} \mathrm{I}^{-1}$, respectively, for $A$. dracunculus and $A$. annua) indicated that insect neural sites are targeted by the EOs toxicity. Finally, the antibacterial and antifungal activities of the two Artemisia EOs may assist in the reduction of transmission of microbial infections/contaminations.

Conclusions: Results suggest that Artemisia EOs could be of use in the control of C. vomitoria, a common vector of pathogenic microorganisms and agent of human and animal cutaneous myiasis. The prevention of pathogenic and parasitic infections is a priority for human and animal health. The Artemisia EOs could represent an eco-friendly, low-cost alternative to synthetic repellents and insecticides to fight synanthropic disease-carrying blowflies.
\end{abstract}

Keywords: Botanical insecticides, Repellent, Blowflies, Acetylcholinesterase, Bactericidal, Fungicidal

\section{Background}

Blowflies (Diptera: Calliphoridae) are problematic pests, important vectors of many foodborne, human, and domestic animal pathogens [1-4]. Feeding in animal and human excrement, garbage, and decaying organic matter, blowflies can spread microorganisms through direct contamination of food and surfaces through fecal deposits, and extracorporeal digestion (fly spots) $[5,6]$ causing the spread of foodborne illnesses and other diseases. In fact, blowflies have been showed to transport a variety of bacteria, cestodes, protozoans and viruses of

\footnotetext{
* Correspondence: barbara.conti@unipi.it

${ }^{1}$ Department of Agriculture, Food and Environment, University of Pisa, Via del Borghetto 80, 56124 Pisa, Italy

Full list of author information is available at the end of the article
}

public health importance such as Salmonella typhimurium [7], Taenia spp., Entamoeba coli, Giardia duodenalis [8], Mycobacterium avium paratuberculosis [9] as well as the avian influenza virus [10]. Blowflies are also characterized by the ability of their larvae to develop in the tissues of vertebrates causing myiasis, a worldwide severe medical and veterinary problem [11-13].

The bluebottle fly Calliphora vomitoria (L.) is a common blowfly frequently recorded in synanthropic and natural ecosystems in most areas of the world [14], and is a vector of pathogenic microorganisms [5]. Moreover, C. vomitoria maggots have been recorded in human and animal cutaneous myiasis $[15,16]$.

The prevention of blowfly infestations has traditionally relied on synthetic insecticides such as organochlorines, 
organophosphates and insect growth regulators $[17,18]$. However, the repeated insurgence of blowfly resistance to chemicals [19] and, the issues around the harmful effects of synthetic compounds on humans [20, 21], animals [22] and the environment [23], have made new eco-friendly, low-cost tools a high priority. In this regard, essential oils (EOs) of aromatic plants, which are often characterized by low toxicity towards mammalians [24] and high biodegradability, have recently received increased attention as natural products effective as contact and fumigant insecticides and as repellents against insect pests [25-28].

Artemisia annua L. and Artemisia dracunculus L. (Asteraceae) are aromatic plants whose EOs are known for their antibacterial, antifungal and insecticidal properties $[29,30]$. This study aimed to assess the toxic and oviposition deterrent activity of A. annua and A. dracunculus EOs against $C$. vomitoria. For that purpose, $A$. annua and $A$. dracunculus EOs were extracted, chemically analysed and tested in laboratory bioassays against C. vomitoria. The physiological mechanisms of EOs insect toxicity were evaluated by enzymatic inhibition tests. Moreover, in consideration that blowflies are vectors of pathogens, the antibacterial and antifungal properties of $A$. annua and $A$. dracunculus EOs were also evaluated against Escherichia coli, Bacillus subtilis, Streptococcus aureus and Candida albicans which are considered among the most common and harmful microbial species in mammals.

\section{Methods}

\section{Flies rearing}

Larvae of the bluebottle fly $C$. vomitoria were purchased from a commercial supplier (Fish Company Arco Sport, Cascina PI, Italy). The larvae were fed with beef liver and maintained under laboratory condition $\left(23{ }^{\circ} \mathrm{C}, 60\right.$ $70 \%$ R.H., natural photoperiod) until pupation. Species identification of the emerged adults was confirmed by a dipterologist (Prof. Alfio Raspi, Department of Agriculture, Food and Environment, University of Pisa). After identification, 20 flies were placed in a $27 \times 27 \times 27 \mathrm{~cm}$ cage, provided with solid diet (sugar and yeast 1:1) and water ad libitum. The sugar-yeast diet was previously shown to be successful in providing protein amounts necessary to stimulate oviposition of Calliphoridae [31, 32]. For the oviposition, beef liver was provided to females. Newly emerged larvae were fed on beef liver as well until pupation. The resulting adult C. vomitoria population was maintained under laboratory conditions.

\section{Plant material}

The flowering aerial parts of $A$. annua were collected in Pisa (Italy) at the end of September 2015 along the Arno riverbanks. Aerial parts of $A$. dracunculus were collected in June 2015, during the flowering period, near Urbino, (Italy), at $500 \mathrm{~m}$ above sea level. The plant material was dried at room temperature in the shadow until constant weight.

\section{EO extraction and chemical characterisation}

$A$. annua and $A$. dracunculus aerial parts were hydrodistilled in a Clevenger-type apparatus for $2 \mathrm{~h}$. Gas chromatography-electron impact mass spectroscopy (GC-EIMS) analyses were performed with a Varian CP3800 gas chromatograph, equipped with a DB-5 capillary column $(30 \mathrm{~m} \times 0.25 \mathrm{~mm}$; coating thickness $0.25 \mu \mathrm{m})$ and a Varian Saturn 2000 ion trap mass detector. Analytical conditions included injector and transfer line temperatures $220{ }^{\circ} \mathrm{C}$ and $240{ }^{\circ} \mathrm{C}$, respectively, oven temperature programmed from 60 to $240{ }^{\circ} \mathrm{C}$ at $3{ }^{\circ} \mathrm{C} /$ min, carrier gas helium at $1 \mathrm{ml} / \mathrm{min}$, injection of $0.2 \mu \mathrm{l}$ (10\% hexane solution), and a split ratio of $1: 30$. Constituent identification was based on comparison of retention times with those of authentic samples, by comparing their linear retention indices (LRI) with the series of $n$-hydrocarbons and using computer matching against commercial [33] and home-made library mass spectra (built up from pure substances and components of known oils and mass spectra literature data) [33, 34].

\section{Contact toxicity bioassays}

The two EOs were tested for contact toxicity against 710 day-old adults of $C$. vomitoria. Flies were treated by topical applications of the EOs with a Burkard microapplicator. A $1 \mathrm{ml}$ syringe was used and $2 \mu \mathrm{l}$ of $10,20,30$ and, $40 \% \mathrm{EtOH}$ solutions of the EO, corresponding to $0.2,0.4,0.6$ and $0.8 \mu \mathrm{l} \mathrm{EO}$ insect $^{-1}$ was applied on the thorax of ten unsexed adult flies. Four replicates $(40$ treated flies) were run for each dose. Control flies (40 each) were treated with $2 \mu \mathrm{l}$ of ethanol. To allow the topical application of the EOs, flies were anesthetised by keeping them at $-20{ }^{\circ} \mathrm{C}$ for $3 \mathrm{~min}$. Insects were maintained in Plexiglas cages of $20 \mathrm{~cm}$ of diameter and $30 \mathrm{~cm}$ long (ten insects per cage) with water and sugar ad libitum under laboratory conditions $\left(23^{\circ} \mathrm{C}, 75 \% \mathrm{RH}\right)$. Mortality of the flies was checked daily (every $24 \mathrm{~h}$ ) for 4 days $(96 \mathrm{~h}$ ) and values were corrected using the Abbott formula [35].

\section{Fumigation toxicity bioassays}

Ten unsexed adult flies were placed in an airtight glass jar $(330 \mathrm{ml})$ with a screw cap. A piece of filter paper was adhered inside the cap. One hundred microliters of 10 , 20, 30 and, $40 \% \mathrm{EtOH}$ solutions of the EOs, corresponding to $30,60,90$, and $120 \mu \mathrm{l}$ of $\mathrm{EO} / \mathrm{l}^{-1}$ of air, were applied to the filter paper. The treated filter paper was protected from direct contact with the insect by a thin layer of sterile gauze. The control jars were treated with 
EtOH. The jars were further sealed with Parafilm and maintained at $23 \pm 1{ }^{\circ} \mathrm{C}, 75 \% \mathrm{RH}$. Each test was replicated four times and mortality was checked at $24 \mathrm{~h}$.

\section{Oviposition deterrence}

One hundred and fifty unsexed, 10-14 day-old, C. vomitoria adults, were placed into $75 \times 75 \times 115 \mathrm{~cm}$ cages (BugDorm-2400 Insect Rearing Tent, MegaView Science Co., Ltd., Taiwan). The flies were fed with sugar and yeast after emergence and for the whole duration of the test. Dissection and examination of a subsample of females prior to the commencement of the assays confirmed that all of them were gravid. In each cage, flies were let to lay eggs on beef meatballs $(5 \mathrm{~g})$ placed on Petri dishes bases $(4 \mathrm{~cm}$ of diameter). To prevent desiccation, the meat of each meatball was mixed with $1 \mathrm{ml}$ of water and $3 \mathrm{ml}$ of water was poured on the bottom of the Petri dish as well. The surface of the meatballs was treated by a glass nebulizer with $100 \mu \mathrm{l}$ of $0,0.1,0.5$, or $1 \% \mathrm{EtOH}$ solution of the EOs, corresponding to 0.000 (control), 0.005, 0.025, and $0.050 \mu \mathrm{l} \mathrm{EO}$ $\mathrm{cm}^{-2}$. Four meatballs, one for each treatment dose, were placed at each corner of the cage about $10 \mathrm{~cm}$ from the edge. Cages were collocated under fluorescent lamps, to provide even lighting (light intensity at the cages of about $14 \operatorname{lux}$ ), and were maintained at $23{ }^{\circ} \mathrm{C}$ and approximately $75 \% \mathrm{RH}$. A beaker containing $500 \mathrm{ml}$ of water was positioned in each cage to maintain humidity inside the cage. The eggs laid were counted after $24 \mathrm{~h}$ from the beginning of the test by the piece counter function of an analytical balance. The experiment was replicated three times.

The percent effective repellence (ER\%) for each concentration was calculated using the following formula [36]:

$$
\mathrm{ER} \%=[(\mathrm{NT}-\mathrm{NC}) / \mathrm{NC} \times 100
$$

Oviposition Activity Index (OAI) was calculated using the formula:

$$
\mathrm{OAI}=(\mathrm{NT}-\mathrm{NC}) /(\mathrm{NT}+\mathrm{NC})
$$

where, NT is the total number of eggs on the treated meatball and $\mathrm{NC}$ is the total number of eggs on the control meatball [37].

\section{AChE extraction and inhibition assay}

Extraction of AChE was performed as described by Seo et al. [38]. In brief, an aliquot ( $300 \mathrm{mg}$ ) of adult insects were homogenized in $4 \mathrm{ml}$ of buffer $(10 \mathrm{mM}$ Tris- $\mathrm{HCl}$, $\mathrm{pH} 8.0)$ containing $0.5 \%(\mathrm{v} / \mathrm{v})$ Triton X-100 and $20 \mathrm{mM}$ $\mathrm{NaCl}$. The homogenate was centrifuged at $17,000 \times g$ at $4{ }^{\circ} \mathrm{C}$ for $15 \mathrm{~min}$ and the supernatant containing AChE was filtered through glass wool to remove excess lipid. Total protein content was quantified by the Protein Assay Kit $\mathrm{II}^{\odot}$ (Bio-Rad) and AChE extracted was used for AChE assays.
Inhibition of AChE was determined by the colorimetric method of Ellman et al. [39] using acetylthiocholine (ATCh) as the substrate. Protein content of AChE extract was diluted to $0.1 \mathrm{mg} \mathrm{ml}^{-1}$ and the reaction mixture consisted of $500 \mu \mathrm{l}$ of diluted $\mathrm{AChE}$ extract (which contained $0.05 \mathrm{mg}$ protein $\mathrm{ml}^{-1}$ ) and $50 \mu \mathrm{l}$ of EOs for each concentration $(2,5,25,50,100,125,250$ and $500 \mathrm{mg} \mathrm{l}^{-1}$ dissolved in $5 \%(\mathrm{v} / \mathrm{v})$ acetone). Controls were prepared adding acetone at the same concentration and without EOs. The tube was set on incubator at $25{ }^{\circ} \mathrm{C}$ for $5 \mathrm{~min}$ before adding $100 \mu \mathrm{l}$ of $0.01 \mathrm{M} \mathrm{5,5'-dithiobis-(2-}$ nitrobenzoic acid) (DTNB; dissolved in phosphate buffer $\mathrm{pH} 7.0$ ) and $2.4 \mathrm{ml}$ of phosphate buffer ( $\mathrm{pH}$ 8.0). Mixture was gently agitated and maintained under incubation for further $10 \mathrm{~min}$ at $25{ }^{\circ} \mathrm{C}$ before adding $40 \mu \mathrm{l}$ of $75 \mathrm{mM}$ ATCh (dissolved in $0.1 \mathrm{M}$ phosphate buffer $\mathrm{pH}$ 8.0) and the mixture was then incubated for $20 \mathrm{~min}$ at $25{ }^{\circ} \mathrm{C}$. The activity of AChE was measured at $25{ }^{\circ} \mathrm{C}$ from the increase of absorbance at $412 \mathrm{~nm}$ by a Ultrospec 2100 Pro spectrophotometer (GE Healthcare Ltd, England). Inhibition percentage of $\mathrm{AChE}$ activity was calculated as follows:

$$
\text { AChEinhibition } \%=(1-\mathrm{SAT} / \mathrm{SAC}) \times 100
$$

where SAT is the specific activity of the enzyme in treatment and SAC is specific activity of the enzyme in control. Residual percentage of AChE activity was calculated as $(\mathrm{SAT} / \mathrm{SAC}) \times 100$. Three replicates were measured for each EOs concentration.

\section{Antimicrobial activity assay}

The essential oils were individually tested against Escherichia coli ATCC 10536, Staphylococcus aureus ATCC BAA-1026, Bacillus subtilis ATCC 11774 and Candida albicans ATCC 10231. All the strains were purchased from the American Type of Culture Collection (ATCC, Manassan, USA) and maintained in the Laboratories of the Universidad Tecnica del Norte, Ecuador. E. coli, S. aureus and $B$. subtilis strains were grown on nutrient agar; C. albicans strain was grown on malt agar. The microbial strains were selected as representative of the main microbial groups agent of foodborne illnesses and other diseases of human health importance.

The antibacterial activity of EOs was determined by the agar disc diffusion method (Kirby-Bauer) as described by the Clinical and Laboratory Standards Institute (CLSI) protocol [40], with some modifications, as follows. Active microbial suspensions were made from 24-h-old agar plates using sterile saline solution until a

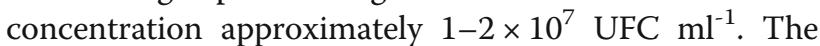
microbial suspension was streaked over the surface of Mueller Hinton agar (MHA, Oxoid SpA, Milano, Italy) plates using a sterile cotton swab to obtain uniform 
Table 1 Chemical composition (\%) of the Artemisia annua and Artemisia dracunculus essential oils used in the assays

\begin{tabular}{|c|c|c|c|}
\hline Constituent $^{\mathrm{a}}$ & $L R I$ & A. annua & A. dracunculus \\
\hline Santolina triene & 911 & 0.6 & nd \\
\hline Tricyclene & 928 & 0.1 & nd \\
\hline a-pinene & 941 & 5.7 & 2.6 \\
\hline Camphene & 955 & 2.4 & 0.4 \\
\hline Sabinene & 978 & 1.8 & nd \\
\hline$\beta$-pinene & 981 & 1.1 & 3.4 \\
\hline Myrcene & 993 & 2.8 & 0.3 \\
\hline Yomogi alcohol & 999 & 1.4 & nd \\
\hline Pseudolimonene & 1004 & nd & 0.3 \\
\hline$\delta$-3-carene & 1013 & nd & 0.3 \\
\hline a-terpinene & 1020 & 0.3 & 0.8 \\
\hline p-cymene & 1028 & 0.2 & 0.4 \\
\hline Limonene & 1032 & nd & 5.4 \\
\hline 1,8-cineole & 1042 & 18.8 & 3.0 \\
\hline (Z)- $\beta$-ocimene & 1043 & nd & 3.0 \\
\hline 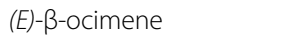 & 1052 & nd & 5.3 \\
\hline$\gamma$-terpinene & 1062 & nd & 0.4 \\
\hline Artemisia ketone & 1063 & 22.1 & 0.4 \\
\hline cis-sabinene hydrate & 1070 & 0.3 & nd \\
\hline Artemisia alcohol & 1085 & 5.9 & nd \\
\hline Isoterpinolene & 1088 & nd & 0.3 \\
\hline Terpinolene & 1090 & nd & 1.3 \\
\hline cis-p-menth-2-en-1-ol & 1123 & 0.2 & nd \\
\hline a-campholenal & 1126 & 0.3 & nd \\
\hline allo-ocimene & 1131 & nd & 0.2 \\
\hline trans-pinocarveol & 1141 & 2.2 & nd \\
\hline neo-allo-ocimene & 1144 & nd & 0.3 \\
\hline camphor & 1145 & 16.9 & nd \\
\hline$\beta$-pinene oxide & 1158 & 1.5 & nd \\
\hline Pinocarvone & 1164 & 3.0 & nd \\
\hline$\delta$-terpineol & 1167 & 0.4 & nd \\
\hline 4-terpineol & 1179 & 1.2 & nd \\
\hline a-terpineol & 1191 & 0.6 & 1.3 \\
\hline Myrtenol & 1195 & 0.6 & nd \\
\hline Methyl chavicol & 1197 & nd & 73.3 \\
\hline Hexyl 3-methylbutanoate & 1244 & 0.2 & nd \\
\hline Isobornyl acetate & 1287 & nd & 0.2 \\
\hline a-copaene & 1377 & 0.2 & nd \\
\hline Benzyl isovalerate & 1384 & 0.2 & nd \\
\hline Methyl eugenol & 1403 & nd & 0.2 \\
\hline a-cedrene & 1409 & nd & 0.1 \\
\hline$\beta$-caryophyllene & 1419 & 1.8 & 0.1 \\
\hline (E)- $\beta$-farnesene & 1459 & 0.1 & nd \\
\hline
\end{tabular}

Table 1 Chemical composition (\%) of the Artemisia annua and Artemisia dracunculus essential oils used in the assays (Continued)

\begin{tabular}{lccl}
\hline Germacrene D & 1481 & 2.2 & nd \\
$\beta$-selinene & 1487 & 0.6 & nd \\
Bicyclogermacrene & 1495 & 0.5 & nd \\
a-bulnesene & 1507 & 0.2 & nd \\
Caryophyllene oxide & 1582 & 0.3 & nd \\
Total identified & & 96.7 & 99.9 \\
\hline
\end{tabular}

Abbreviations: $L R I$ linear retention index on DB-5 column, nd not detected

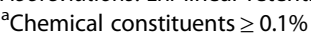

microbial growth. Under aseptic conditions, filter paper discs (diameter $6 \mathrm{~mm}$, Whatman paper No.1, Oxoid) were placed on the agar plates (one disc per Petri dish to avoid any possible additive activity) and then $10 \mu \mathrm{l}$ of each EO dilutions (corresponding to 10, 5, 2.5, 1.25, and $0.63 \mu \mathrm{l}$ EOs per disc) was put on the discs. Control discs contained $10 \mu \mathrm{l}$ of methanol. The inoculated plates were then incubated at $37{ }^{\circ} \mathrm{C}$ for $24 \mathrm{~h}$. Microbial inhibition zones were measured using a digital calliper and expressed in millimetres $(\mathrm{mm})$. Six repetitions were made for each treatment.

The minimal inhibitory concentration (MIC) and the minimal lethal concentration (MLC) were determined according to the modified procedure of Yadegarinia et al. [41] as follows: $5 \mathrm{ml}$ of $10^{7} \mathrm{UFC} \mathrm{ml}^{-1}$ microbial broth were incubated in a series of tubes containing $50 \mu \mathrm{l}$ of decreasing concentration of the oil $(10,5,2.5,1.25$ and, $0.63 \mu \mathrm{l} \mathrm{EO}$ per tube). The tubes were incubated at $37^{\circ} \mathrm{C}$ for $48 \mathrm{~h}$ under aerobic conditions and, after incubation, the growth was visually assessed. The MIC was defined as the lowest concentration of compound without visible growth. From the tubes showing no growth, $10 \mu \mathrm{l}$ were subcultured on agar plates to determine if the inhibition was reversible or permanent. The results of the subculture were used to calculate the minimal lethal concentration (MLC). The MLC was defined as the lowest compound concentration which caused the death of

Table 2 Principal chemical classes (\%) in the Artemisia annua and Artemisia dracunculus essential oils used in the assays

\begin{tabular}{lcc}
\hline Chemical classes & A. annua & A. dracunculus \\
\hline Monoterpene hydrocarbons & 15.0 & 24.3 \\
Oxygenated monoterpenes & 75.4 & 1.9 \\
Sesquiterpene hydrocarbons & 5.6 & 0.2 \\
Oxygenated sesquiterpenes & 0.3 & 0.0 \\
Phenylpropanoids & 0.0 & 73.5 \\
Non-terpene derivatives & 0.4 & 0.0 \\
Total identified & 96.7 & 99.9 \\
\hline
\end{tabular}


Table 3 Oviposition deterrent effect of the Artemisia annua and Artemisia dracunculus essential oils (EOs) against Calliphora vomitoria. Data are presented as the mean \pm standard error

\begin{tabular}{llcl}
\hline & $\mathrm{EO}\left(\mu \mathrm{cm}^{-2}\right)$ & No. of eggs laid & $\mathrm{ER}(\%)$ \\
\hline A. annua & 0 & $613.67 \pm 58.21 \mathrm{a}$ & $0.00 \pm 0.00 \mathrm{~A}$ \\
& 0.005 & $539.33 \pm 399.70 \mathrm{ab}$ & $13.82 \pm 28.27 \mathrm{~A}$ \\
& 0.025 & $180.00 \pm 180.00 \mathrm{bc}$ & $-69.31 \pm 9.35 \mathrm{~A}$ \\
& 0.050 & $123.00 \pm 123.00 \mathrm{C}$ & $-78.80 \pm 6.24 \mathrm{~A}$ \\
A. dracunculus & 0 & $2344.67 \pm 520.97 \mathrm{a}$ & $0.00 \pm 0.00 \mathrm{~A}$ \\
& 0.005 & $2685.67 \pm 540.93 \mathrm{a}$ & $17.51 \pm 10.62 \mathrm{~A}$ \\
& 0.025 & $76.00 \pm 76.00 \mathrm{~b}$ & $-96.77 \pm 0.63 \mathrm{~B}$ \\
& 0.050 & $0.00 \pm 0.00 \mathrm{~b}$ & $-100.00 \pm 0.00 \mathrm{~B}$ \\
\hline
\end{tabular}

Note: Different lower case letters indicate significant differences in total no. of eggs laid among different doses of each EO (GLM, Tukey HSD, $P \leq 0.05$ ). Different upper case letters indicate significant differences in ER between the same doses of each EO (Mann-Whitney U-test, $P \leq 0.05$ ) Abbreviation: $E R$ (\%) percent effective repellence

99.9\% of the microbial inoculum. Three repetitions were made for each treatment.

\section{Statistics and data analyses}

Essential oil median lethal dose $\left(\mathrm{LD}_{50}\right)$ and median lethal concentration $\left(\mathrm{LC}_{50}\right)$ against $C$. vomitoria adults were calculated by Log-probit regressions. Significant differences between the $\mathrm{LD}_{50}$ and the $\mathrm{LC}_{50}$ values of the two EOs were determined by estimation of confidence intervals of the relative median potency ( $\mathrm{rmp}$ ). Differences between $\mathrm{LD}_{50}$ and $\mathrm{LC}_{50}$ values were considered statistically significant when values in the $95 \%$ confidence interval of relative median potency analyses were $\neq 1.0$. Effective oviposition deterrence and residual AChE activity percentage data were transformed into arcsine values before statistical analysis and processed using GLM univariate ANOVA with EO and the dose as factors. $P$-values $<0.05$ were considered significant. $\mathrm{IC}_{50}$

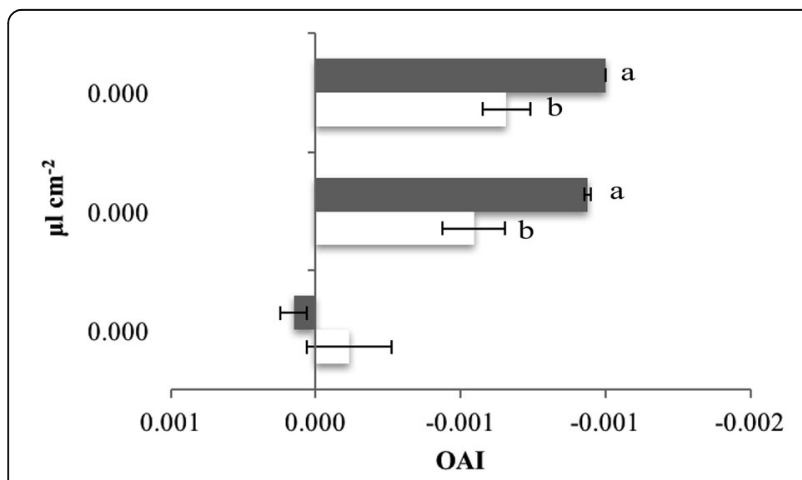

Fig. 1 Oviposition deterrency by Artemisia annua and Artemisia dracunculus essential oils. Histograms represent the oviposition activity index (OAI) values. OAl of -0.3 and below are considered as repellents; 0.3 and above, as attractive [68]. White bars, A. annua EO; grey bars, A. dracunculus EO. Intervals in black represent standard errors values of AChE activity (inhibitory concentration needed to inhibit $50 \%$ of the enzyme activity, negative Hill slope) were calculated by nonlinear regression to a fourparameter logistic equation (variable Hill slope). Differences in sizes of inhibitory zones formed by EOs against different microbial strains were tested by Kruskal-Wallis test and means separated by Dunn-Bonferroni pairwise comparisons. Statistics were performed by SPSS 22.0 (SPSS Inc., Chicago, IL, USA) and by GraphPad Prism 5 software (GraphPad Software, San Diego, CA, USA).

\section{Results}

\section{EOs extraction and GC-MS analysis}

Essential oil yield (w/w) of A. annua was $2.25 \%$ dry weight, whereas the yield of $A$. dracunculus was $0.40 \%$. The two EOs were pale yellow with a very aromatic, long-lasting smell.

In the A. апnua EO, 34 constituents were identified, accounting for $96.7 \%$ of the whole oil. In the $A$. dracunculus EO, 24 constituents were identified, accounting for 99.9\% of the whole oil. The principal chemical constituent of the $A$. annua EO was artemisia ketone (22.1\%), followed by 1,8 -cineole $(18.8 \%)$, whereas methyl chavicol (73.3\%) was the main chemical in the A. dracunculus EO. Other important volatiles were camphor (16.9\%), artemisia alcohol (5.9\%) and $\alpha$-pinene (5.7\%) for $A$. annua $\mathrm{EO}$, and limonene and (E)- $\beta$-ocimene (5.4 and $5.3 \%$, respectively) for $A$. dracunculus EO (see Table 1).

Phenylpropanoids and monoterpene hydrocarbons (73.5 and 24.3\%, respectively) represented the main chemical classes of $A$. annua EO and oxygenated monoterpenes and monoterpene hydrocarbons (75.4 and $15.0 \%$, respectively) of $A$. dracunculus EO. For $A$. annua, another important class of chemical constituents was sesquiterpene hydrocarbons (5.6\%) (Table 2).

\section{Oviposition deterrence}

Both Artemisia EOs deterred C. vomitoria oviposition starting from the dose of $0.025 \mu \mathrm{cm}^{-2}$. At $0.050 \mu \mathrm{l} \mathrm{cm}$ ${ }^{2}$, A. dracunculus EO completely inhibited C. vomitoria oviposition (Table 3, Fig. 1). Moreover, ANOVA showed a significantly different effect of the tested chemical on the oviposition deterrence $\left(F_{(1,16)}=7.577, P=0.014\right)$ and of the dose $\left(F_{(3,16)}=16.993, P<0.001\right)$ with interaction effect $\quad\left(F_{(3,16)}=5.117, \quad P=0.011\right)$. Starting from $0.025 \mu \mathrm{cm}^{-2}$ the $A$. dracunculus EO was more effective than EO from $A$. annua (Table 3 ).

\section{Adulticidal activity}

Artemisia EOs showed good adulticidal activity, both by contact and fumigation, against the fly $C$. vomitoria even at low doses. By contact, EOs $\mathrm{LD}_{50}$ values were 0.485 to $0.786 \mu \mathrm{l}$ per individual for $A$. dracunculus and $A$. annua, respectively. By fumigation, $\mathrm{LC}_{50}$ values were 49.55 to 
Table 4 Toxicity of Artemisia annua and Artemisia dracunculus essential oils (EOs) against adults of Calliphora vomitoria by contact and fumigation

\begin{tabular}{llclccc}
\hline EO & Method & $\mathrm{LD}_{50}^{\mathrm{a}} / \mathrm{LC} \mathrm{C}_{50}^{\mathrm{b}}$ & $95 \% \mathrm{Cl}$ & $\mathrm{Slope} \pm \mathrm{SE}$ & $\operatorname{Intercept} \pm \mathrm{SE}$ & $X^{2}(d f)$ \\
\hline A. annua & Contact & 0.79 & $0.65-1.13$ & $3.62 \pm 0.84$ & $0.38 \pm 0.25$ & $\mathbf{2 . 9 8}(2)$ \\
& Fumigation & 88.09 & $75.07-107.94$ & $10.65 \pm 1.58$ & $-20.71 \pm 3.05$ & $\mathbf{5 . 6 8}(3)$ \\
A. dracunculus & Contact & 0.49 & $0.33-0.68$ & $5.16 \pm 0.81$ & $1.62 \pm 0.27$ & $\mathbf{6 . 3 1}(3)$ \\
& Fumigation & 49.55 & $44.28-54.33$ & $6.48 \pm 0.82$ & $-10.98 \pm 1.45$ & $\mathbf{3 . 0 7}(2)$ \\
\hline
\end{tabular}

Abbreviations: $\mathrm{Cl}$ confidence interval, $d f$ degrees of freedom, $S E$ standard error

Note: Values in bold indicate $P>0.05$ )

${ }^{a}$ Dose of EO that kills $50 \%$ of the insects treated by direct contact

${ }^{\mathrm{b}}$ Concentration of EO that kills $50 \%$ of the insects treated by fumigation. Data were calculated by Probit regression analysis and expressed as $\mu \mathrm{l}$ insect ${ }^{-1}$ for contact tests and as $\mu \mathrm{I} \mathrm{I}^{-1}$ air for fumigation tests

$88.09 \mu \mathrm{l} \mathrm{l}^{-1}$ of air for $A$. dracunculus and A. annua, respectively (Table 4). Relative toxicity, calculated by rmp analyses, indicated that $A$. апnиa EO was significantly more effective than $A$. dracunculus EO both by contact and fumigation (Table 5).

\section{AChE inhibition}

Both the Artemisia EOs inhibited the AChE of C. vomitoria. The AChE inhibitory activity of the two Artemisia EOs is summarized in Table 6. The inhibitory effect of the two Artemisia EOs was dose-dependent $\left(F_{(6,14)}=13.947\right.$, $P<0.001 ; F_{(6,14)}=40.738, P<0.001$, for $A$. annua and $A$. dracunculus, respectively). In general, EO from $A$. dracunculus was found to be a stronger inhibitor of $\mathrm{AChE}$ in $C$. vomitoria $\left(\mathrm{IC}_{50}=202.6 \mathrm{mg} \mathrm{l}^{-1}\right)$ compared with $A$. annua $\mathrm{EO}\left(\mathrm{IC}_{50}=472.4 \mathrm{mg} \mathrm{l}^{-1}\right)($ Table 7$)$.

\section{Antimicrobial activity assay}

The results of the antimicrobial activity of $A$. annua and $A$. dracunculus EOs revealed significant antibacterial activity whose magnitude varied depending on the EO (KruskalWallis, $X_{(1)}^{2}=22.485, P<0.001$ ), the microbial strain (Kruskal-Wallis, $\left.\chi_{(3)}^{2}=66.039, P<0.001\right)$ and, the EO concentration (Kruskal-Wallis, $\chi_{(4)}^{2}=115.945, P<0.001$ ). The diameter of inhibition zones of the tested EOs from both Artemisia spp. measured by disc agar diffusion method is presented in Table 8. The inhibition zone of $A$. dracunculus EO ranged from $3.5 \pm 0.3$ to $35.2 \pm 0.6 \mathrm{~mm}$ for 0.63 and $10 \mu \mathrm{lisc}^{-1}$, respectively, while $A$. annua inhibited microbial growth for a radius up to $29.3 \pm 0.6 \mathrm{~mm}\left(10 \mu \mathrm{l} \mathrm{disc}{ }^{-1}\right)$. At $10 \mu \mathrm{ldisc}^{-1}$, the largest inhibition zones were obtained by $A$. dracunculus

Table 5 Relative toxicity, calculated by relative median potency analyses (rmp), of Artemisia annua vs Artemisia dracunculus essential oils against adults of Calliphora vomitoria by contact and fumigation

\begin{tabular}{lccc}
\hline Method & Estimate $^{\mathrm{a}}$ & Lower bound & Upper bound \\
\hline Contact & $\mathbf{1 . 5 2 9}$ & 1.084 & 2.917 \\
Fumigation & $\mathbf{1 . 7 5 8}$ & 1.264 & 3.443
\end{tabular}

Note: Bold indicates significant values $(95 \% \mathrm{Cl} \neq 1)$

${ }^{a_{r m p}}$ values $>1$ indicate less efficacy of $A$. annua vs $A$. dracunculus EO
EO against $C$. albicans $(35.2 \pm 0.6 \mathrm{~mm})$, while the narrowest was obtained by $A$. annua $\mathrm{EO}$ against $S$. aureus $(7.3 \pm$ $0.5 \mathrm{~mm})$. Accordingly, MIC and MLC values showed that the most susceptible microbial pathogen was $C$. albicans $(A$. annua EO MIC and MLC $\leq 0.63 \mu \mathrm{l} \mathrm{ml}^{-1} ; A$. dracunculus EO MIC and $\mathrm{MLC} \leq 0.63$ and, $1.25 \mu \mathrm{l} \mathrm{ml}{ }^{-1}$, respectively) (Table 9) while, $S$. aureus was the less susceptible microorganism to A. annua $\mathrm{EO}$ (MIC =10.0; MLC > 10.0). Overall, $A$. dracunculus $\mathrm{EO}$ showed the strongest and consistent inhibitory effect on microbial growth with values $\leq$ $0.63 \mu \mathrm{l} \mathrm{ml}^{-1}$ for all the microorganisms tested (Table 9).

\section{Discussion}

The composition of $A$. annua and $A$. dracunculus EOs is known to be quite variable depending upon the climate, the extraction method, the plant part, the geographic location, the chemotype and, the plant genotype (for recent reviews about $A$. апnua EO see [42] and regarding A. dracunculus EO see $[43,44])$.

Chemical analyses showed quantitative and qualitative differences in the chemical composition of the two EOs. In fact, phenylpropanoids, the main chemical class of constituents of the $A$. dracunculus EO (73.5\%), are completely absent in $A$. annua. On the contrary, the $\mathrm{EO}$ of $A$. annua was characterized by high percentages of oxygenated

Table 6 Artemisia annua and Artemisia dracunculus essential oils in vitro inhibition of acetylcholinesterase extracted from adults of Calliphora vomitoria. Data are expressed as the percentage of residual activity and represent the mean of three replicates \pm SE

\begin{tabular}{llc}
\hline $\mathrm{mg} \mathrm{l}^{-1}$ & A. annua & A. dracunculus \\
\hline 2 & $96.9 \pm 1.4 \mathrm{a}$ & $98.9 \pm 1.8 \mathrm{a}$ \\
5 & $95.7 \pm 5.0 \mathrm{a}$ & $96.9 \pm 5.0 \mathrm{a}$ \\
25 & $98.2 \pm 9.3 \mathrm{a}$ & $96.9 \pm 4.2 \mathrm{a}$ \\
50 & $84.7 \pm 2.5 \mathrm{ab}$ & $72.4 \pm 1.2 \mathrm{~b}$ \\
100 & $82.2 \pm 2.1 \mathrm{ab}$ & $72.5 \pm 4.3 \mathrm{~b}$ \\
125 & $67.9 \pm 1.8 \mathrm{bc}$ & $59.3 \pm 2.9 \mathrm{bc}$ \\
250 & $54.8 \pm 2.9 \mathrm{c}$ & $44.2 \pm 1.9 \mathrm{c}$ \\
\hline
\end{tabular}

Note: Different letters indicate significant differences (GLM, Tukey HSD posthoc test, $P<0.05$ ) within columns 
Table 7 Artemisia annua and A. dracunculus essential oils (EOs) $\mathrm{IC}_{50}$ values of Calliphora vomitoria acetylcholinesterase (AChE) in vitro activity. Data are calculated by non-linear regression

\begin{tabular}{llll}
\hline EO & $I_{50}$ & $R^{2}$ & $d f$ \\
\hline A. annua & 472.4 & 0.909 & 20 \\
A. dracunculus & 202.6 & 0.907 & 21 \\
\hline
\end{tabular}

Abbreviations: $I C_{50}$ concentration $\left(\mathrm{mg} \mathrm{l}^{-1}\right)$ of EO that inhibits $50 \%$ of the AChE activity, $d f$ degrees of freedom

monoterpenes $(75.4 \%)$, which constitute a minor chemical class in A. dracunculus (1.5\%).

Essential oils have been consistently shown to be toxic and repellent against insect pests, though to date, very few studies have been conducted on their use against Calliphoridae species. In this study, both A. annua and A. dracunculus EOs, although different in chemical composition, displayed both toxic and repellent activities against $C$. vomitoria. At a dose of $0.05 \mu \mathrm{cm}^{-2}(100 \mu \mathrm{l}$ of 1\% EtOH/5 g meatball), A. dracunculus EO completely inhibited $C$. vomitoria oviposition. In line with our results, a complete inhibition of oviposition was previously observed for $L$. cuprina on media treated with tea tree EO [45].

The observed differences in effectiveness of the two EOs could be due to their different chemical composition. However, the complexity of the insect olfactory system makes it difficult to clarify how chemical information encoded in the repellent molecules is perceived by the insect to produce a behavioural response [46]. $A r$ temisia dracunculus EO $(1 \mathrm{ml} \mathrm{EO}$ in polyethylene foam wafer) has also been showed to reduce, in field conditions, the attraction of adult Japanese beetles, Popillia japonica Newman (Coleoptera: Scarabaeidae), to attractant-baited or non-baited traps [47] and, in an olfactometer study, A. dracunculus EO $(2 \mu \mathrm{l}$ of EO in $2 \mathrm{~g}$ of food) showed significant repellent activity against adults of the indianmeal moth, Plodia interpunctella [48]. Similarly, A. апnиa EO was found to be repellent against adults of Tribolium castaneum (Herbst) at 1\% (vol/vol) concentration and above in filter paper arena test [30].

Artemisia annua and A. dracunculus EOs were also toxic by contact and fumigation against adults of $C$. vomitoria, although $A$. dracunculus $\mathrm{EO}$ were significantly more effective than that from A. annua. A different efficacy of EOs from different plants is expected although they belong to the same genera. In this case, the different bioactivity of the two EOs may be due to their very different chemical composition. For example, methyl chavicol, the main constituent (73.3\%) of $A$. dracunculus EO, was absent in A. annua EO.

The differing efficacies of the two Artemisia EOs is confirmed by the 2-fold higher inhibitory effect on $\mathrm{AChE}$ activity exerted by $A$. dracunculus $\mathrm{EO}\left(\mathrm{IC}_{50}=\right.$ 202.6) as compared to that of $A$. annua $\left(\mathrm{IC}_{50}=472.4\right)$. A similar inhibition of insect AChE activity has been already shown by several plant extracts $[38,49]$ and by some monoterpene constituents of EOs, which have indeed been recognized as the strongest inhibitors contained in EOs of different plant species [50, 51]. It has been demonstrated that the ability of monoterpenes to inhibit the AChE activity is related to their competition with the active site of the free enzyme (competitive inhibition) [51] or due to their ability to bind to either the free enzyme (but combining to a site different from the active site where the substrate binds) or the enzymesubstrate complex (mixed inhibition) [51]. In view of the above, if it was only the monoterpenoids that were suppressing $\mathrm{AChE}$, one would expect a higher $\mathrm{AChE}$ inhibition for $\mathrm{EO}$ of $A$. апnua, which is richer in monoterpenoids ( $90 \%$ ) than $A$. dracunculus ( 26\%). However, monoterpenoids can also be active as synergists in the inhibition of

Table 8 Antibacterial activity (inhibition zone, mm) of Artemisia annua and Artemisia dracunculus essential oils (EOs) against Escherichia coli, Bacillus subtilis, Streptococcus aureus and Candida albicans microbial strains. Data are presented as the mean \pm standard error

\begin{tabular}{llllcl}
\hline EO & Dose $\left({ }^{\mathrm{a}} \mu \mathrm{l}\right.$.disc $\left.{ }^{-1}\right)$ & E. coli & B. subtilis & S. aureus & C. albicans \\
\hline A. annua & 10 & $20.8 \pm 0.5 \mathrm{bBC}$ & $18.0 \pm 0.9 \mathrm{bAB}$ & $7.3 \pm 0.5 \mathrm{bA}$ & $29.3 \pm 0.6 \mathrm{bB}$ \\
& 5 & $13.0 \pm 0.5 \mathrm{bBC}$ & $14.3 \pm 0.2 \mathrm{bAB}$ & $0.8 \pm 0.3 \mathrm{bA}$ & $21.7 \pm 0.6 \mathrm{bC}$ \\
& 2.5 & $8.7 \pm 0.6 \mathrm{abB}$ & $8.0 \pm 0.4 \mathrm{abB}$ & $0.0 \pm 0.0 \mathrm{aA}$ & $17.5 \pm 0.7 \mathrm{abB}$ \\
& 1.25 & $1.7 \pm 0.2 \mathrm{aB}$ & $1.3 \pm 0.2 \mathrm{aB}$ & $0.0 \pm 0.0 \mathrm{aA}$ & $11.0 \pm 0.5 \mathrm{aB}$ \\
& 0.63 & $0.0 \pm 0.0 \mathrm{aA}$ & $0.0 \pm 0.0 \mathrm{aA}$ & $0.0 \pm 0.0 \mathrm{aA}$ & $5.3 \pm 0.6 \mathrm{aB}$ \\
A. dracunculus & 10 & $15.2 \pm 0.2 \mathrm{bA}$ & $32.0 \pm 1.0 \mathrm{~b} \mathrm{AB}$ & $14.3 \pm 0.2 \mathrm{bA}$ & $35.2 \pm 0.6 \mathrm{bB}$ \\
& 5 & $12.2 \pm 0.4 \mathrm{abA}$ & $21.2 \pm 0.6 \mathrm{abAB}$ & $11.5 \pm 0.2 \mathrm{abA}$ & $31.2 \pm 0.8 \mathrm{bB}$ \\
& 2.5 & $9.5 \pm 0.6 \mathrm{abA}$ & $16.0 \pm 0.4 \mathrm{abAB}$ & $7.3 \pm 0.3 \mathrm{abA}$ & $28.5 \pm 0.3 \mathrm{abB}$ \\
& 1.25 & $8.3 \pm 0.3 \mathrm{aAB}$ & $9.0 \pm 0.5 \mathrm{aAB}$ & $5.7 \pm 0.2 \mathrm{aA}$ & $13.3 \pm 0.6 \mathrm{abB}$ \\
& 0.63 & $7.8 \pm 0.3 \mathrm{aAB}$ & $8.3 \pm 0.4 \mathrm{aB}$ & $5.3 \pm 0.3 \mathrm{aAB}$ & $3.5 \pm 0.3 \mathrm{aA}$ \\
\hline
\end{tabular}

Note: different lower case letters indicate significant differences among different doses of each EO; different capital letters indicate significant differences among microbial strains at the same doses of each EO (Kruskal-Wallis, Dunn-Bonferroni pairwise comparisons, $P \leq 0.05$ ) 
Table 9 Minimum inhibitory concentration (MIC) and minimum lethal concentration (MLC) values of the essential oils (EOs) of Artemisia annua and Artemisia dracunculus against Escherichia coli, Bacillus subtilis, Streptococcus aureus and Candida albicans microbial strains

\begin{tabular}{lllll}
\hline Microorganism & \multicolumn{2}{l}{ A. annua EO } & \multicolumn{2}{l}{ A. dracunculus EO } \\
\hline & MIC & MLC & MIC & MLC \\
E. coli & $1.25^{\text {a }}$ & 5.00 & 0.63 & 2.50 \\
B. subtilis & 2.50 & 5.00 & 0.63 & 2.50 \\
S. auerus & 10.00 & $>10.00$ & 0.63 & 2.50 \\
C. albicans & 0.63 & 0.63 & 0.63 & 1.25 \\
\hline a ml $^{-1}$ & & & &
\end{tabular}

${ }^{\mathrm{a}} \mu \mathrm{l} \mathrm{ml^{-1 }}$

AChE [52] and thus the EO profile can be more relevant on AChE inhibition than the simple sum of their amount. In addition, it has been also demonstrated that some phenolic acids strongly inhibit the activity of AChE [51, 53, 54]. For example, López \& Pascual-Villalobos [51] demonstrated that methyl chavicol, which represent about the $73 \%$ of the whole EO of $A$. dracunculus, is one of the most powerful $\mathrm{AChE}$ inhibitors in vitro. In a subsequent paper the same authors confirmed the strong AChE inhibition ability of this compound on Sitophilus oryzae and Cryptolestes pusillus [54]. The inhibitory effect of the two Artemisia EOs on the AChE activity suggest that the targets of their toxicity are $C$. vomitoria neuromuscular sites, the same target sites of insecticides belonging to the organophosphorus and carbamate group $[55,56]$. Thus, from an applicative point of view, although EOs could represent a valid alternative to synthetic pesticides, the possibility of insurgence of cross-resistance cannot be excluded [57].

Besides the repellent and toxic effect against $C$. vomitoria, the two Artemisia EOs showed good antibacterial and antifungal activity except for the $A$. апnиa EO against $S$. aureus. Since wounds represent sites of preference for C. vomitoria oviposition, such antimicrobial activity can be useful in preventing secondary infections. Essential oils are lipophiles that can enter cells and interfere with the integrity and functionality of the membrane [58]. The resulting membrane permeabilisation is expected to cause loss of ions, reduction of potential, the collapse of proton pump and the depletion of ATP pool [59]. The monoterpene thymol has been shown to cause disruption of the cellular membrane, inhibition of ATPase activity, and release of intracellular ATP and other constituents $[60,61]$. However, probably due to the large number of different chemical components, EOs antibacterial activity is not attributable to one specific mechanism [62] and although the antimicrobial activity of EOs is mainly due to their major components, synergistic or antagonistic effects of minor compounds should also be considered $[63,64]$.
Both the Artemisia EOs showed a strong effect against the pathogenic fungus $C$. albicans. In line with our findings, $C$. albicans was reported to be highly susceptible also to Myrtus communis and Mentha piperita EOs [41] as well as to Origanum spp. EOs $[65,66]$. The action of EOs against fungi appears to be similar to those against bacteria. Tolouee et al. [67] showed that M. chamomilla EOs affects the permeability of Aspergillus niger plasma membrane causing imbalance in intracellular osmotic pressure, disruption of intracellular organelles, leakage of cytoplasmic contents and finally cell death.

\section{Conclusions}

The prevention of pathogenic and parasitic infections is a priority for human and animal health. The efficacy of Artemisia EOs against the blowflies coupled with their low-cost and low-toxicity against mammals suggests that EOs could represent an alternative "soft" way to fight foodborne disease, infection, and myiasis. However, further studies are needed to establish the modality of EOs formulation and applications i.e. by microencapsulation or gel that may enable a constant release of volatiles and maximize the efficacy of the treatments.

\section{Abbreviations}

AChE: Acetylcholinesterase; ATCC: American Type of Culture Collection; ATCh: Acetylthiocholine; ATP: Adenosintriphosphate;

ATPase: Adenosintriphosphate synthase; CLSI: Clinical and Laboratory Standards Institute; EO: Essential oil; ER\%: Percent effective repellence; EtOH: Ethyl alcohol; GC-EIMS: Gas chromatography-electron impact mass spectroscopy; GLM: General linear model; $\mathrm{I}_{50}$ : Concentration that inhibits $50 \%$ of the activity; $L C_{50}$ : Concentration that kills $50 \%$ of the insects treated; $\mathrm{LD}_{50}$ : Dose that kills $50 \%$ of the insects treated; LRI: Linear retention index; MHA: Mueller Hinton agar; OAl: Oviposition activity; RH: Relative humidity; rmp: Relative median potency; SAC: Specific activity of the enzyme in control; SAT: Specific activity of the enzyme in treatment

\section{Acknowledgements}

We are very grateful to Professor Alfio Raspi for the C. vomitoria identification, to Paolo Giannotti for the technical assistance and to Dr Riccardo Antonelli for the photographs of the insects.

\section{Funding}

This research has been supported by the University of Pisa Research Grants (2015) and by the MIUR (Italian Minister of University and Research) (Prin 2015, protocol 2015BABFCF).

\section{Availability of data and material}

The data supporting the conclusions of this article are included within the article. Raw data and materials are available from the corresponding author upon request.

\section{Authors' contributions \\ SB: Experimental design, Flies rearing, Repellency and toxicity tests, statistical analyses, manuscript writing; GF: Essential oils extraction, Mass spectrometry analysis; FC: Flies rearing, Repellency and toxicity tests ; RA: Essential oils extraction, Mass spectrometry analysis; MCE: Antimicrobial activity tests; LG: Enzymatic tests, manuscript writing; ML: Enzymatic tests, statistical analyses; AL: Experimental design, manuscript writing; BC: Experimental design, Flies rearing, Repellency and toxicity tests, manuscript writing. All authors read and approved the final manuscript.}

\section{Competing interests}

The authors declare that they have no competing interests. 


\section{Consent for publication}

Not applicable.

\section{Ethics approval and consent to participate}

Not applicable.

\section{Author details}

'Department of Agriculture, Food and Environment, University of Pisa, Via del Borghetto 80, 56124 Pisa, Italy. ${ }^{2}$ Department of Pharmacy, University of Pisa, Via Bonanno 6, 56126 Pisa, Italy. ${ }^{3}$ Universidad Tecnica del Norte, v 17 de Julio 5-21, Ibarra, Ecuador.

\section{Received: 21 October 2016 Accepted: 27 January 2017}

Published online: 13 February 2017

\section{References}

1. Greenberg B. Flies and diseases, vol. 1, Ecology Classification and Biotic Associations. Princeton: Princeton University Press; 1971.

2. Daniel M, Kovacova D, Roslerova V, Zuska J. Synanthropic flies and other insects in the hospital area and microflora detected on the surface of their bodies. Cesk Epidemiol Mikrobiol Imunol. 1990;39:21-31 (in Czech).

3. Graczyk TK, Knight R, Gilman RH, Cranfield MR. The role of non-biting flies in the epidemiology of human infectious diseases. Microbes Infect. 2001;3:231-5.

4. Pava-Ripoll M, Pearson REG, Miller AK, Ziobro GC. Prevalence and relative risk of Cronobacter spp., Salmonella spp., and Listeria monocytogenes associated with the body surfaces and guts of individual filth flies. App Environ Microbiol. 2012;78:7891-902.

5. Förster M, Klimpel S, Mehlhorn H, Sievert K, Messler S, Pfeffer K. Pilot study on synanthropic flies (e.g. Musca, Sarcophaga, Calliphora, Fannia, Lucilia, Stomoxys) as vectors of pathogenic microorganisms. Parasitol Res. 2007;101:243-6.

6. Förster M, Sievert K, Messler S, Klimpel S, Pfeffer K. Comprehensive study on the occurrence and distribution of pathogenic microorganisms carried by synanthropic flies caught at different rural locations in Germany. J Med Entomol. 2009:46:1164-6.

7. Greenberg B, Kowalski JA, Klowden MJ. Factors affecting the transmission of Salmonella by flies: natural resistance to colonization and bacterial interference. Infect Immun. 1970;2:800-9.

8. Mariluis JC, Lagar MC, Bellegarde EJ. Disemination of enteroparasites by Calliphoridae (Insecta, Diptera). Mem Inst Oswaldo Cruz. 1989;84:349-51.

9. Fischer O, Matlova L, Dvorska L, Švástová P, Bartl J, Melicharek I, et al. Diptera as vectors of mycobacterial infections in cattle and pigs. Med Vet Entomol. 2001;15:208-11.

10. Sawabe K, Hoshino K, Isawa H, Sasaki T, Kim KS, Hayashi T, et al. Blow flies were one of the possible candidates for transmission of highly pathogenic H5N1 avian influenza virus during the 2004 outbreaks in Japan. Influenza Res Treat. 2011;Article ID 652652:1-8.

11. Wall R. Ovine cutaneous myiasis: effects on production and control. Vet Parasitol. 2012;189:44-51.

12. Millán $\mathrm{CL}$, Olea MS, Juri MJD. Unusual presence of Ornidia robusta (Diptera: Syrphidae) causing pig myiasis in Argentina. Parasitol Res. 2015;114:4731-5.

13. Hall MJ, Wall RL, Stevens JR. Traumatic myiasis: a neglected disease in a changing world. Annu Rev Entomol. 2016;61:159-76.

14. Szpila K, Pape T, Hall MJR, Madra A. Morphology and identification of first instars of European and Mediterranean blowflies of forensic importance. Part III: Calliphorinae. Med Vet Entomol. 2014;28:133-42.

15. Alexander JOD. Cutaneous myiasis. In: Arthropods and Human Skin. London: Springer; 1984. p. 87-113.

16. Morris OS, Titchener RN. Blowfly species composition in sheep myiasis in Scotland. Med Vet Entomol. 1997;22:253-6.

17. French NP, Wall R, Cripps PJ, Morgan KL. Prevalence, regional distribution and control of blowfly strike in England and Wales. Vet Rec. 1992;131:337-42.

18. Baker KE, Rolfe PF, George AG, Vanhoof KJ, Kluver PF, Bailey JN. Effective control of a suspected cyromazine-resistant strain of Lucilia cuprina using commercial spray-on formulations of cyromazine or dicyclanil. Aust Vet $\mathrm{J}$. 2014:92:376-80.

19. Levot GW. Cyromazine resistance detected in Australian sheep blowfly. Aust Vet J. 2012:90:433-43.

20. Roldán-Tapia L, Parrón T, Sánchez-Santed F. Neuropsychological effects of long-term exposure to organophosphate pesticides. Neurotoxicol Teratol. 2005;27(2):259-66
21. Stephens R, Spurgeon A, Calvert LA, Beach J, Levy LS, Berry H, Harrington JM. Neuropsycological effects of long-term exposure to organophosphates in sheep dip. Lancet. 1995;345:1135-9.

22. Tellam RL, Bowles VM. Control of blowfly strike in sheep: current strategies and future prospects. Int J Parasitol. 1997;27:261-73.

23. Littlejohn JW, Melvin MAL. Sheep-dips as a source of pollution of freshwaters, a study in Grampian Region. J Inst Water Env Man. 1991;5:1-27.

24. Regnault-Roger C, Vincent C, Arnason JT. Essential oils in insect control: lowrisk products in a high-stakes world. Annu Rev Entomol. 2012;57:405-24.

25. Isman MB. Plant essential oils for pest and disease management. Crop Prot. 2000;19:603-8.

26. Isman MB. Botanical insecticides, deterrents, and repellents in modern agriculture and an increasingly regulated world. Annu Rev Entomol. 2006;51:45-66.

27. Nerio LS, Olivero-Verbel JS, Tashenko E. Repellent activity of essential oils from seven aromatics plants grown in Colombia against Sitophilus zeamais Motschulsky (Coleoptera). J Stored Prod Res. 2009;45:212-4.

28. Bedini S, Flamini G, Girardi J, Cosci F, Conti B. Not just for beer: evaluation of spent hops (Humulus lupulus) as a source of eco-friendly repellents for insect pests of stored foods. J Pest Science. 2015;88:583-92.

29. Kordali S, Kotan R, Mavi A, Cakir A, Ala A, Yildirim A. Determination of the chemical composition and antioxidant activity of the essential oil of Artemisia dracunculus and of the antifungal and antibacterial activities of Turkish Artemisia absinthium, A. dracunculus, Artemisia santonicum, and Artemisia spicigera essential oils. J Agr Food Chem. 2005;53:9452-8.

30. Tripathi AK, Prajapati V, Aggarwal KK, Khanuja SP, Kumar S. Repellency and toxicity of oil from Artemisia annua to certain stored-product beetles. J Econ Entomol. 2000;93:43-7

31. Ujvari B, Wallman JF, Madsen T, Whelan M, Hulbert AJ. Experimental studies of blowfly (Calliphora stygia) longevity: a little dietary fat is beneficial but too much is detrimental. Comp Biochem Phys A. 2009;154:383-8.

32. Kelly MA, Zieba AP, Buttemer WA, Hulbert AJ. Effect of temperature on the rate of ageing: an experimental study of the blowfly Calliphora stygia. PLoS One. 2013;8, e73781

33. Adams RP. Identification of essential oil components by gas chromatography/ mass spectroscopy. 4th ed. Illinois: Allured Publ. Corp., Carol Stream; 2007.

34. Davies NW. Gas chromatographic retention indices of monoterpenes and sesquiterpenes on methyl silicon and carbowax $20 \mathrm{M}$ phases. J Chromatogr. 1990;503:1-24.

35. Abbot WJ. A method of computing effectiveness of an insecticide. J Econ Entomol. 1925;18:256-67.

36. Rajkumar S, Jebanesan A. Larvicidal and oviposition activity of Cassia obtusifolia Linn (Family: Leguminosae) leaf extract against malarial vector, Anopheles stephensi Liston (Diptera: Culicidae). Parasitol Res. 2009;104:337-40.

37. Cheah SX, Tay JW, Chan LK, Jaal Z. Larvicidal, oviposition, and ovicidal effects of Artemisia annua (Asterales: Asteraceae) against Aedes aegypti, Anopheles sinensis, and Culex quinquefasciatus (Diptera: Culicidae). Parasitol Res. 2013;112:3275-82.

38. Seo SM, Jung CS, Kang J, Lee HR, Kim SW, Hyun J, Park IK. Inhibitory activities of apiaceae plant essential oils and their constituents against Aedes albopictus and formulation development. J Agr Food Chem. 2015;63:9977-86.

39. Ellman G, Courtney KD, Andres V, Featerstone RM. A new and rapid colorimetric determination of acetylcholinesterase activity. Biochem Pharmacol. 1961;7:88-90.

40. Wayne PA. Performance standards for antimicrobial susceptibility testing. In: Clinical and laboratory standards institute (CLSI), 20th Informational Supplement (M100-S20). 2010. p. 32-43.

41. Yadegarinia D, Gachkar L, Rezaei MB, Taghizadeh M, Astaneh SA, Rasooli I. Biochemical activities of Iranian Mentha piperita L. and Myrtus communis L. essential oils. Phytochemistry. 2006;67:1249-55.

42. Bilia AR, Santomauro F, Sacco C, Bergonzi MC, Donato R. Essential oil of Artemisia annua L.: an extraordinary component with numerous antimicrobial properties. Evidence-based complementary and alternative medicine. 2014; doi: 10.1155/2014/159819.

43. Fraternale D, Flamini G, Ricci D. Essential oil composition and antigermination activity of Artemisia dracunculus (Tarragon). Nat Prod Commun. 2015;10:1469-72.

44. Ayoughi F, Marzegar M, Sahari MA, Naghdibadi H. Chemical compositions of essential oils of Artemisia dracunculus L. and endemic Matricaria chamomilla L. and an evaluation of their antioxidative effects. J Agr Sci Tech. 2010;13:79-88

45. Callander JT, James PJ. Insecticidal and repellent effects of tea tree (Melaleuca alternifolia) oil against Lucilia cuprina. Vet Parasitol. 2012;184:271-8. 
46. Carey AF, Wang G, Su CY, Zwiebel LJ, Carlson JR. Odorant reception in the malaria mosquito Anopheles gambiae. Nature. 2010;464:66-71.

47. Youssef NN, Oliver JB, Ranger CM, Reding ME, Moyseenko JJ, Klein MJ, Pappas RS. Field evaluation of essential oils for reducing attraction by the Japanese beetle (Coleoptera: Scarabaeidae). J Econ Entomol. 2009;102:1551-8.

48. Karahroodi ZR, Moharramipour S, Rahbarpour A. Investigated repellency effect of some essential oils of 17 native medicinal plants on adults Plodia interpunctella. Am-Eurasian J Sustain Agric. 2009;3:181-4.

49. Ryan MF, Byrne O. Plant insect coevolution and inhibition of acetylcolinesterase. J Chem Ecol. 1988;14:1965-75.

50. Shaaya E, Rafaeli A. Essential oils as biorational insecticides-potency and mode of action. In: Ishaaya A, Neuen R, Horowitz AR, editors. Insecticides design using advanced technologies. Germany: Springer; 2007. p. 249-61.

51. López MD, Pascual-Villalobos MJ. Mode of inhibition of acetylcholinesterase by monoterpenoids and implications for pest control. Ind Crop Prod. 2010; 31:284-8.

52. Savelev S, Okello E, Perry NSL, Wilkins RM, Perry EK. Synergistic and antagonistic interactions of anticholinesterase terpenoids in Salvia lavandulaefolia essential oil. Pharmacol Biochem Behav. 2003;75:661-8.

53. Doi S, Terasaki M, Makino M. Acetylcholinesterase inhibitory activity and chemical composition of commercial essential oils. J Agr Food Chem. 2009; 57:4313-8.

54. López MD, Pascual-Villalobos MJ. Are monoterpenoids and phenylpropanoids efficient inhibitors of acetylcholinesterase from stored product insect strains? Flavour Frag J. 2015;30:108-12.

55. Matsumura F. Toxicology of insecticides. 2nd ed. USA: Plenum Press; 1985.

56. Yu SJ. The toxicology and biochemistry of insecticides. USA: CRC Press; 2008.

57. Lee SE, Choi WS, Lee HS, Park BS. Cross-resistance of a chlorpyrifos-methyl resistant strain of Oryzaephilus surinamensis (Coleoptera: Cucujidae) to fumigant toxicity of essential oil extracted from Eucalyptus globulus and its major monoterpene, 1, 8-cineole. J Stored Prod Res. 2000;36:383-9.

58. Perricone M, Arace E, Corbo MR, Sinigaglia M, Bevilacqua A. Bioactivity of essential oils: a review on their interaction with food components. Front Microbiol. 2015;6:1-7.

59. Bakkali F, Averbeck S, Averbeck D, Idaomar M. Biological effects of essential oils-a review. Food Chem Toxicol. 2008;46:446-75.

60. Viuda-Martos M, Ruiz Navajas Y, Zapata ES, Fernández-López J, Pérez-Álvarez JA. Antioxidant activity of essential oils of five spice plants widely used in a Mediterranean diet. Flavour Frag J. 2010;25:13-9.

61. Viuda-Martos M, Mohamady M, Fernández-López J, Abd ElRazik KA, Omer EA, Pérez-Alvarez JA, Sendra E. In vitro antioxidant and antibacterial activities of essentials oils obtained from Egyptian aromatic plants. Food Control. 2011;22:1715-22

62. Burt S. Essential oils: their antibacterial properties and potential applications in foods - a review. Int J Food Microbiol. 2004;94:223-53.

63. Daferera DJ, Basil N, Ziogas N, Polissiou MG. The effectiveness of plant essential oils on Botrytis cinerea, Fusarium sp. and Clavibacter michiganensis subsp. michiganensis. Crop Prot. 2003:22:39-44.

64. Bougherra HH, Bedini S, Flamini G, Cosci F, Belhamel K, Conti B. Pistacia lentiscus essential oil has repellent effect against three major insect pests of pasta. Ind Crop Prod. 2015;63:249-55.

65. Ibrahim L, Karaky M, Ayoub P, El Ajouz N, Ibrahim S. Chemical composition and antimicrobial activities of essential oil and its components from Lebanese Origanum syriacum L. J Essent Oil Res. 2012;24:339-45.

66. Portillo-Ruiz MC, Sánchez RAS, Ramos SV, Muñoz JVT, Nevárez-Moorillón GV Antifungal effect of Mexican oregano (Lippia berlandieri Schauer) essential oil on a wheat flour-based Medium. J Food Sci. 2012;77:M441-5.

67. Tolouee M, Alinezhad S, Saberi R, Eslamifar A, Javad Zad S, Jaimand K, et al. Effect of Matricaria chamomilla L. flower essential oil on the growth and ultrastructure of Aspergillus niger van Tieghem. Int J Food Microbiol. 2010;139:127-33.

68. Kramer WL, Mulla S. Oviposition attractants and repellents of mosquitoes: oviposition responses of Culex mosquitoes to organic infusions. Environ Entomol. 1979:8:1111-7. 